\title{
Ekonomiczne determinanty atrakcyjności inwestycyjnej w tle ograniczeń budżetowych
}

Słowa kluczowe: atrakcyjność inwestycyjna, samorząd terytorialny, fundusze strukturalne, Unia Europejska, budżet, polityka finansowa, deficyt budżetowy

Keywords: investment attractiveness, local government, structural funds, European Union, budget, financial policy, budget deficit

\section{Wprowadzenie}

Wejście Polski do Unii Europejskiej (UE) stworzyło nowe możliwości rozwoju społeczno-gospodarczego praktycznie we wszystkich obszarach funkcjonowania państwa, w tym również dla jednostek samorządu terytorialnego. Już przed przystąpieniem Polski do UE jednostki samorządowe korzystały ze środków pomocowych funduszy przedakcesyjnych, co miało na celu wesprzeć rozwój państw kandydujących i zarazem zmniejszyć różnice gospodarcze. Reaktywowanie samorządu na najniższym gminnym szczeblu i nowy podział administracyjny w Polsce, istniejący od 1999 roku, był jednym z czynników umożliwiających dążenie naszego kraju do akcesji do Unii Europejskiej. Przystąpienie do Wspólnoty wiązało się z przeprowadzeniem w Polsce reform gospodarczych i koniecznością dostosowania przepisów prawa w wielu obszarach funkcjonowania państwa. Zmiany te nie zakończyły się wraz z przystąpieniem do UE, ale są kontynuowane, ponieważ członkostwo obliguje do przestrzegania zasad wspólnotowych. B. Porębska (2014) pisze, że jedną z korzyści wynikających z bycia członkiem Unii Europejskiej jest możliwość m.in. korzystania z funduszy pomocowych. Jednym z istotnych

* Dorota Miśkiewicz, Uniwersytet Szczeciński, doktorantka na Wydziale Zarządzania i Ekonomiki Usług, e-mail: dorotamiskiewicz1@wp.pl 
aspektów funkcjonowania układów lokalnych są zadania stojące przed władzami lokalnymi, zmierzające do wprowadzania instrumentów i stosowania takich narzędzi polityki rozwoju lokalnego, które spowodują podniesienie poziomu atrakcyjności inwestycyjnej regionu. Poziom atrakcyjności inwestycyjnej gminy ma bezpośrednie przełożenie na jej możliwości konkurencyjne w procesie pozyskiwania inwestorów, $\mathrm{z}$ tego też względu istnieje potrzeba efektywnego posługiwania się różnorodnymi narzędziami kreowania wyżej wspomnianej atrakcyjności przez władze samorządowe. Identyfikacja determinant ekonomicznych i barier rozwoju lokalnego jest istotna z punktu widzenia podejmowania właściwych decyzji w procesie stymulowania rozwoju społeczno-gospodarczego regionu. M. Adamowicz (2003) twierdzi, że nie bez znaczenia pozostaje także odpowiednie wypromowanie walorów gminy wśród inwestorów, stąd coraz większy nacisk władze lokalne kładą na działania w tej sferze. Jednostki samorządu terytorialnego (JST) finansują w Polsce ok. 3/4 inwestycji realizowanych w sektorze publicznym, wykorzystując $w$ tym zakresie zróżnicowane źródła finansowania, takie jak np. dochody własne JST (otrzymywane m.in. z podatków i opłat lokalnych, mienia komunalnego), środki zwrotne (kredyty, pożyczki, przychody z emisji obligacji komunalnych), środki pochodzące z sektora prywatnego, pozyskiwane w ramach tzw. projektów mieszanych (realizowanych w formule partnerstwa publiczno-prywatnego) oraz fundusze pomocowe Unii Europejskiej. Środki pomocowe UE stanowią aktualnie istotny - można nawet powiedzieć kluczowy - impuls wzrostu aktywności inwestycyjnej JST w Polsce. M. Poniatowicz (2014) wskazuje, że tendencja ta zostanie utrzymana, a nawet wzmocniona w nowej perspektywie finansowej, to jest w latach 2014-2020. Celem artykułu jest zdiagnozowanie wpływu czynników ekonomicznych na atrakcyjność inwestycyjną JST przy udziale funduszy strukturalnych UE w okresie pogłębiających się ograniczeń budżetowych. W opracowaniu zwrócono uwagę na najważniejsze inwestycje JST w regionie oraz aktualne plany rozwojowe, które będą miały znaczny wpływ na atrakcyjność inwestycyjną regionu. Założony cel uzyskano poprzez analizę danych statystycznych oraz przegląd dokumentów strategicznych opisujących założenia rozwojowe regionu. Za okres badawczy przyjęto ostatni zakończony okres dotacyjny 2007-2013.

\section{Atrakcyjność inwestycyjna - aspekt teoretyczny}

Atrakcyjność inwestycyjna jest pojęciem złożonym, obejmującym wiele czynników ważnych zarówno z punktu widzenia planowanych inwestycji, jak i działań gospodarczych. To, czy region postrzegany jest jako atrakcyjny zależy od oceny inwestora, który analizuje atrakcyjność rynku pod względem czynników produkcji dostępnych w danej gospodarce oraz potencjalnego wzrostu korzyści netto z ulokowania kapitału w postaci 
bezpośrednich inwestycji zagranicznych. Na atrakcyjność inwestycyjną kraju wpływają następujące czynniki ekonomiczne:

- stopień liberalizacji gospodarki,

- poziom fiskalizmu,

- istnienie równowagi społeczno-ekonomicznej,

- struktura własnościowa gospodarki, zmiany w polityce dochodowej państwa,

- tendencje na rynku pracy ze szczególnym naciskiem na poziom jednostkowego kosztu pracy,

- istniejące relacje państwa, przedsiębiorstw i związków zawodowych.

W literaturze przedmiotu można odnaleźć odmienne podejścia do zagadnienia atrakcyjności - w tym atrakcyjności inwestycyjnej - różniące się od siebie przesłaniem i ukierunkowaniem na zrównoważony rozwój. Jak sugerują R. Atkinson, B. Madsen, A. Russo, L. Servillo, I. Smith, J. Van der Borg (2010), w stosunkowo szerokim ujęciu atrakcyjność inwestycyjną należy utożsamiać ze specyficzną cechą regionów lub miast, która w wielu przypadkach jest jednym z warunków wstępnych tworzenia samopodtrzymującego się rozwoju na poziomie regionalnym. Może być ona zdefiniowana jako zdolność do przyciągania nowych mieszkańców, migrantów i turystów, nowych usług działalności gospodarczej, inwestycji, jak i utrzymania potencjalnego rozwoju lokalnej społeczności oraz walorów. Według M. Nazarczuka (2001) atrakcyjność postrzegana jest najczęściej jako cecha charakterystyczna każdego regionu uwarunkowana dostępnymi zasobami i walorami ekonomicznymi, środowiskowymi, społecznymi i kulturalnymi. Inne podejście nakazuje traktować atrakcyjność jako walor bycia atrakcyjnym lub ujmującym (quality of being attracting or engaging). Podstawową miarą atrakcyjności inwestycyjnej kraju jest pozycja inwestycyjna netto, która uwzględnia saldo skumulowanych bezpośrednich inwestycji zagranicznych. Innym kryterium jest udział inwestycji zagranicznych w wartości aktywów kraju. Dzięki temu możemy poznać znaczenie inwestycji zagranicznych w gospodarce. Istotna jest tu zwłaszcza wysokość rocznego napływu bezpośrednich inwestycji zagranicznych w stosunku do całości nakładów inwestycyjnych. Zdecydowana większość inwestycji zagranicznych, czyli ponad 85\%, pochodzi z krajów Unii Europejskiej. W literaturze zauważyć można, że atrakcyjność inwestycyjną kwalifikuje się jako teorię należącą do dziedziny ekonomicznej, wnikliwie opisaną przez wielu naukowców zajmujących się tym tematem. Według J. Dunning (1993), atrakcyjność inwestycyjna wyrażana jest za pomocą konkurencyjności systemu funkcjonowania gospodarki oraz ładu instytucjonalnego i prawnego. Wśród motywów ekspansji przedsiębiorstw na rynki zagraniczne zwraca się uwagę przede wszystkim na chęć poszukiwania nowych zasobów, rynków, dążenie do podnoszenia efektywności prowadzonej działalności gospodarczej lub lepszego wykorzystania zasobów, co można uznać za bazowe źródła kształtowania przewag konkurencyjnych. Z kolei J. Parysek (1995) 
w swoich rozważaniach twierdzi, że występowanie w danym miejscu konkretnego czynnika rozwoju lokalnego wcale nie musi oznaczać autentycznego rozwoju bądź występowania atrakcyjności inwestycyjnej. Czynnik taki należy zauważyć, poznać, ocenić jego wartość użytkową, pozyskać oraz odpowiednio wykorzystać. M. Stawicka, L. Kwieciński i M. Wróblewski (2010) atrakcyjność inwestycyjną definiują jako zdolność do skłonienia przedsiębiorcy do inwestycji na podstawie korzyści lokalizacyjnych, które możliwe są do osiągnięcia $\mathrm{w}$ procesie prowadzenia działalności gospodarczej. Analizując literaturę przedmiotu, można również odnaleźć definicje atrakcyjności odnoszące się do sektorów, z kolei zagadnienie atrakcyjności inwestycyjnej dotyczy węższego zakresu tematycznego. Najczęściej atrakcyjność inwestycyjna wyrażana jest względną atrakcyjnością określonych obszarów w zakresie jakości lokalizacji i absorpcji inwestycji z uwagi na dostępne na danym terenie walory, to jest dostępność i jakość czynników produkcji, surowców, wielkość rynku zbytu, zamożność społeczeństwa, kwalifikacje i zasoby pracowników, jakość infrastruktury technicznej, dostępność ośrodków B+R. Najpopularniejszą przytaczaną definicją atrakcyjności jest atrakcyjność (konkurencyjność) inwestycyjna rozumiana jako:

- „wartość użytkowa regionu jako miejsca lokalizacji firmy, na którą składają się różnorodne czynniki” (Chojnacka, 2007),

- „kombinacja korzyści lokalizacji możliwych do osiągnięcia w trakcie prowadzenia działalności gospodarczej i wynikających ze specyficznych cech obszaru, w którym działalność ma miejsce" (Kalinowski, 2005),

- zespół „regionalnych walorów lokalizacyjnych, które mają wpływ na osiągnięcie celów inwestora" (np. koszty działalności, przychody ze sprzedaży, rentowność), (Godlewska-Majkowska, 2008),

- „możliwość realizowania renty lokalizacyjnej danego obszaru. Renta jest równa nadwyżce zanotowanego poziomu inwestycji ponad »modelowy« poziom, wynikający z ogólnej zależności inwestowania od uwarunkowań społeczno-gospodarczych" (Guzik, 2010),

- zdolność do „skłonienia inwestorów do wyboru regionu jako miejsca lokalizacji inwestycji” (Nazarczuk, 2001),

- „zdolność skłonienia do inwestycji, poprzez oferowanie kombinacji korzyści lokalizacji możliwych do osiągnięcia w trakcie prowadzenia działalności gospodarczej” (Nowicki, 2010),

- „zdolność do skłaniania inwestorów do wyboru gminy (regionu) jako miejsca lokalizacji inwestycji” (Nazarczuk, 2001).

M. Nowicki (2011) definiuje atrakcyjność inwestycyjną jako zdolność danego obszaru do przyciągania inwestorów. Twierdzi on, że o atrakcyjności inwestycyjnej danej gminy najczęściej decyduje kombinacja czynników. H. Godlewska-Majkowska (2012) 
w swoich publikacjach przedstawia atrakcyjność jako zjawisko o istotnym znaczeniu dla rozwoju regionalnego i lokalnego. Według niej obszar atrakcyjny to taki, który charakteryzuje się walorami lokalizacyjnymi istotnymi dla inwestora i tym samym przyciąga inwestycje, co wywołuje efekt rozwojowy poprzez tworzenie bazy ekonomicznej, a w konsekwencji takich działań przyczynia się do zwiększenia potencjału społeczno-gospodarczego danego regionu. Zdaniem M. Nazarczuka (2001) atrakcyjność regionu jest najważniejszą siłą wpływającą na koncentrację kapitału finansowego i ludzkiego. Warto także pamiętać, że koncentracja działalności gospodarczej determinuje atrakcyjność inwestycyjną, w związku z tym należy uznać, że pomiędzy tymi kategoriami ekonomicznymi istnieją dwustronne zależności. Atrakcyjność inwestycyjna implikuje częściowo wysokość wpływów budżetowych JST, uzyskiwanych z podatków od przedsiębiorstw. Regiony bardziej atrakcyjne stwarzają szanse na generowanie $\mathrm{z}$ tego tytułu wyższych dochodów własnych. Godlewska-Majkowska (2012) jednoznacznie twierdzi, że inwestycje pobudzają rozwój gospodarczy, ponieważ uruchamiają mechanizm rozwoju „od góry” i „od dołu”, co należy rozpatrywać nie tylko z punktu widzenia możliwości zaspokojenia potrzeb przestrzennych i realizacji celów ekonomicznych przedsiębiorców, ale również pod względem poszukiwania obszarów o dobrych warunkach dla rozwoju nowej przedsiębiorczości. Autorka atrakcyjność inwestycyjną rozróżnia w odniesieniu do wskaźników potencjalnej i rzeczywistej atrakcyjności inwestycyjnej na potrzeby jej waloryzacji. Według Godlewskiej-Majkowskiej potencjalna atrakcyjność inwestycyjna to zespół regionalnych walorów lokalizacyjnych, które wpływają na osiąganie celów inwestora, natomiast rzeczywista atrakcyjność inwestycyjna oznacza zdolność regionu do tworzenia satysfakcji klienta-inwestora oraz wywołania absorpcji kapitału finansowego i rzeczowego w formie inwestycji. Uważa ona także, że atrakcyjność inwestycyjna danej lokalizacji często jest rozważana w kontekście decyzji przedsiębiorstw (Godlewska-Majkowska 2011). Spowodowane jest to coraz częstszymi działaniami władz lokalnych w celu pozyskania inwestorów zewnętrznych. Kolejną definicję przytacza E. Bojar (2001), który wskazuje, że specyficzne cechy poszczególnych miejsc, czyli tak zwane czynniki lokalizacji wpływają bezpośrednio na kształtowanie się nakładów inwestycyjnych i skłaniają do inwestowania. O atrakcyjności inwestycyjnej danej gminy najczęściej decyduje kombinacja czynników. T. Kalinowski (2006) twierdzi natomiast, że za atrakcyjne inwestycyjnie uznaje się lokalizacje z najwyższymi walorami użytkowymi dla prowadzonej działalności. Poniatowicz (2014) zauważa, że kluczowe, z punktu widzenia poziomu przyszłej aktywności inwestycyjnej gmin, będą możliwości zapewnienia przez JST tak zwanego wkładu własnego w projektach infrastrukturalnych, wymaganego przy absorpcji środków unijnych. Przy podejmowaniu decyzji dotyczących finansowania projektów inwestycyjnych środkami pochodzącymi z Unii Europejskiej decydenci samorządowi muszą brać pod uwagę możliwość 
zapewnienia wkładu własnego, którego wymóg wynika z jednej z zasad unijnej polityki strukturalnej, to jest zasady współfinansowania. Jak sugerują M. Sierak i J. Bitner (2013) prognozowany łączny wkład własny JST, niezbędny do zapewnienia współfinansowania projektów UE, wynosi ok. 60,6 mld PLN (szacunki przy łącznych środkach UE przewidzianych dla JST w okresie 2014-2020 w wysokości 107,2 mld PLN). W syntetyczny sposób podeszli do zagadnienia atrakcyjności K. Gawlikowska-Hueckel i S. Umiński (2000), twierdząc, że atrakcyjność inwestycyjną należy rozumieć w kategoriach zdolności skłonienia inwestora do wyboru regionu jako miejsca lokalizacji inwestycji. Tak przyjęta definicja pozwala ocenić poziom atrakcyjności inwestycyjnej przez pryzmat wielkości poniesionych nakładów. W. Lizińska, R. Marks-Bielska i R. Kisiel (2011) twierdzą natomiast, że potencjalni zagraniczni inwestorzy, badając atrakcyjność inwestycyjną krajów czy regionów pod względem możliwości lokowania ich kapitału, biorą pod uwagę następujące czynniki: sytuację ekonomiczną, sytuację polityczną i społeczną, regulacje prawne oraz przestrzenny system organizacyjny. Można zatem stwierdzić, że o atrakcyjności inwestycyjnej decydują w głównej mierze dwie grupy czynników gospodarcze (stan gospodarki i perspektywy jej rozwoju) oraz prawne (dotyczące podejmowania i prowadzenia działalności gospodarczej). Atrakcyjność inwestycyjna, jak to opisano powyżej, w istotny sposób wpływa na możliwości rozwoju regionów. Oferowane przez regiony atrakcyjne inwestycyjnie warunki do prowadzenia działalności gospodarczej, wynikające m.in. z dostępności i jakości zasobów, wielkości rynku zbytu, dostępności komunikacyjnej czy realizowanych nakładów na badania i rozwój, sprzyjają rozwojowi zarówno endogenicznej przedsiębiorczości, jak i napływowi inwestycji spoza regionu. Ważną rolę w tej kwestii odgrywają zarówno oferty inwestycyjne, jakie ma do zaproponowania dany obszar, jak i wizerunek inwestycyjny regionu, który może się poprawić poprzez sprawnie prowadzony marketing terytorialny. B. Żelazko (2008) sugeruje, że podstawową rolą atrakcyjności inwestycyjnej w rozwoju na poziomie regionalnym jest stymulowanie inwestycji, które tworzą istotne efekty dla gospodarki całego regionu. Wśród obiektywnych uwarunkowań przemawiających za atrakcyjnością inwestycyjną regionu należy wymienić ogólny poziom jego rozwoju oraz efektywność w działaniach podejmowanych przez instytucje publiczne na rzecz wzmocnienia swojego potencjału.

Regiony z lepszą lokalizacją cechują się większą atrakcyjnością inwestycyjną, stwarzają bowiem lepsze warunki do prowadzenia działalności gospodarczej (np. wymagane są tam mniejsze nakłady inwestycyjne, istnieją szanse na większą rentowność inwestycji), a przez to cechują się mniejszym natężeniem wystąpienia ryzyka inwestycyjnego. Tak rozumiana (potencjalna) atrakcyjność inwestycyjna wskazuje na względne prawdopodobieństwo lokalizacji inwestycji na określonym obszarze. T. Kalinowski (2006) pisze, że z uwagi na odmienne postrzeganie istotności poszczególnych czynników 
lokalizacji przez inwestorów oraz ich wiedzę na temat regionów i branżę, w której działają lub planują rozpocząć działalność, uogólniona dla inwestorów atrakcyjność jest miarą dość przybliżoną, dzięki której można zaprezentować zbiorczą atrakcyjność pod względem lokalizowania inwestycji na danym obszarze (w wielu przypadkach uogólnioną dla różnych branż na podstawie identyfikacji uniwersalnych czynników). Istotną rolę odgrywają również wprowadzane reformy gospodarcze oraz prowadzona polityka gospodarcza, których nadrzędnym celem powinno być znoszenie barier inwestycyjnych i przyczynianie się do poszerzania wolności gospodarczej i konkurencji miedzy podmiotami rynkowymi. Obecność na jednolitym rynku i związane z tym wymierne korzyści głębsza integracja gospodarek czy stabilność regulacji prawnych - poprawiły atrakcyjność inwestycyjną regionów. Na rysunku 1. przedstawiono dwa możliwe warianty wyboru procesu decyzyjnego przez przyszłego inwestora. W wariancie I przedsiębiorca w pierwszej kolejności przeprowadza analizę czynników określających atrakcyjność inwestycyjną gospodarek, a następnie, po dokonaniu wyboru konkretnego kraju, analizuje czynniki lokalne, na podstawie których wybiera region lub miasto, gdzie decyduje się na ulokowanie swojej inwestycji. W wariancie II pokazano sytuację, w której przedsiębiorca swoją uwagę koncentruje przede wszystkim na wyborze konkretnego regionu lub miasta po przeprowadzeniu analizy czynników lokalnych bez szczególnego zwracania uwagi na kraj, w którym dany region lub miasto się znajduje. Dopiero po dokonaniu wyboru regionu lub miejsca przedsiębiorca poddaje analizie czynniki krajowe, które ostatecznie wpływają na podjęcie decyzji.

\section{WARIANT I}

\begin{tabular}{|c|}
\hline $\begin{array}{c}\text { Sporządzenie listy krajów - } \\
\text { potencjalnych lokalizacji inwestycji }\end{array}$ \\
\hline Analiza czynników krajowych \\
\hline Wybór kraju \\
\hline Analiza czynników lokalnych \\
\hline Wybór regionu/miasta \\
\hline
\end{tabular}

\section{WARIANT II}

Sporządzenie listy regionów potencjalnych lokalizacji inwestycji

Analiza czynników lokalnych

Analiza czynników krajowych

Wybór regionu/miasta $\mathrm{z}$

uwzględnieniem uwarunkowań kraju

Rysunek 1. Schematy procesu decyzyjnego inwestora

Badania przeprowadzone przez Instytut Badań nad Gospodarką Rynkową (IBnGR, 2014) oraz przez M. Stawicką, L. Kwiecińskiego i M. Wróblewskiego (2010) wskazują, że około $75 \%$ podejmowanych decyzji inwestycyjnych jest dokonywanych na podstawie wariantu I, czyli najpierw przedsiębiorca wybiera kraj, a następnie region lokalizacji 
swojego zaangażowania kapitałowego. Uwzględniając zróżnicowaną grupę determinant, IBnGR (2014) co roku przeprowadza analizy atrakcyjności inwestycyjnej województw i podregionów Polski, z których sporządza raport odzwierciedlający ranking województw w świetle atrakcyjności inwestycyjnej (tabela 1).

Tabela 1. Czynniki atrakcyjności inwestycyjnej i ich znaczenie w rankingach IBnGR

\begin{tabular}{|c|c|c|c|c|}
\hline & \multicolumn{3}{|c|}{ Podregiony } & \multirow{2}{*}{ Województwa } \\
\hline & przemysł & usługi & $\begin{array}{l}\text { zaawansowane } \\
\text { technologie }\end{array}$ & \\
\hline Czynniki & \multicolumn{3}{|c|}{ Wagi (w \%) } & \\
\hline Dostępność transportowa & 20 & 10 & 20 & 20 \\
\hline Koszty pracy & 15 & 15 & & \multirow[t]{2}{*}{25} \\
\hline Wielkość i jakość zasobów pracy & 40 & 25 & 30 & \\
\hline Chłonność rynku zbytu & & 20 & 10 & 15 \\
\hline Poziom rozwoju infrastruktury gospodarczej & 15 & 10 & 10 & 10 \\
\hline Poziom rozwoju infrastruktury społecznej & & & 10 & 5 \\
\hline Poziom rozwoju gospodarczego & 2 & 5 & 5 & \\
\hline $\begin{array}{l}\text { Stopień ochrony i stan środowiska } \\
\text { przyrodniczego }\end{array}$ & 5 & 7 & 7 & \\
\hline Poziom bezpieczeństwa powszechnego & 3 & 8 & 8 & 5 \\
\hline Aktywność regionów wobec inwestorów & & & & 20 \\
\hline Łacznie & 100 & 100 & 100 & 100 \\
\hline
\end{tabular}

Żródło: opracowanie IBnGR (2014). Raport atrakcyjności inwestycyjnej za 2014 rok.

Korzyści z wyboru lokalizacji dla potencjalnego inwestora mogą być zróżnicowane i wyrażać się, m.in. poprzez koszty prowadzonej działalności gospodarczej, przychody ze sprzedaży, efektywność inwestycyjną czy poziom konkurencyjności. Jednym z warunków koniecznych dla zapewnienia atrakcyjności inwestycyjnej jest dostępność w długim okresie do kapitału finansowego. W tym przypadku dostępność źródeł finansowania, podobnie jak sama atrakcyjność inwestycyjna, warunkowana jest m.in. poprzez zmienną, jaką jest lokalizacja. M. Nowicki (2013) w przeprowadzonych badaniach atrakcyjności inwestycyjnej województw i podregionów Polski w latach 2010-2013, prowadzonych przez Instytut Badań nad Gospodarką Rynkową (IBnGR, 2014) opisał, jak województwa plasują się w rankingu atrakcyjności inwestycyjnej, biorąc pod uwagę wartość wskaźnika syntetycznego (tabela 2). 
Tabela 2. Ranking atrakcyjności inwestycyjnej województw w latach 2010-2013

\begin{tabular}{|c|c|c|c|c|c|c|c|c|c|}
\hline $\begin{array}{l}\text { O } \\
\frac{3}{N} \\
\frac{0}{0} \\
\frac{0}{0} \\
3 \\
3\end{array}$ & 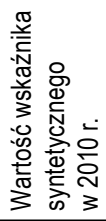 & 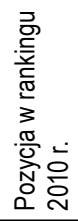 & 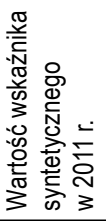 & 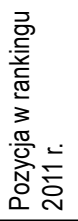 & 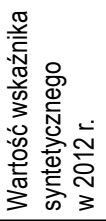 & 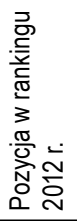 & 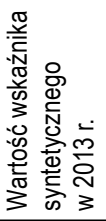 & 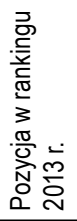 & 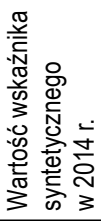 \\
\hline Śląskie & 0,81 & 1 & 0,90 & 1 & 0,86 & 1 & 0,85 & 1 & 0,85 \\
\hline Mazowieckie & 0,50 & 3 & 0,61 & 2 & 0,66 & 2 & 0,46 & 3 & 0,55 \\
\hline Dolnośląskie & 0,61 & 2 & 0,56 & 3 & 0,46 & 3 & 0,50 & 2 & 0,46 \\
\hline Małopolskie & 0,42 & 4 & 0,34 & 4 & 0,26 & 5 & 0,34 & 4 & 0,39 \\
\hline Wielkopolskie & 0,30 & 5 & 0,29 & 5 & 0,33 & 4 & 0,32 & 5 & 0,32 \\
\hline Pomorskie & $-0,04$ & 8 & 0,17 & 7 & 0,12 & 7 & 0,21 & 6 & 0,18 \\
\hline Zachodniopomorskie & 0,29 & 6 & 0,17 & 6 & 0,18 & 6 & 0,18 & 7 & 0,12 \\
\hline Łódzkie & $-0,03$ & 7 & $-0,05$ & 8 & 0,08 & 8 & 0,07 & 8 & 0,10 \\
\hline Opolskie & $-0,08$ & 9 & $-0,19$ & 11 & $-0,19$ & 10 & $-0,09$ & 9 & $-0,11$ \\
\hline Kujawsko-pomorskie & $-0,23$ & 11 & $-0,14$ & 9 & $-0,09$ & 9 & $-0,17$ & 10 & $-0,17$ \\
\hline Lubuskie & $-0,09$ & 10 & $-0,15$ & 10 & $-0,12$ & 11 & $-0,23$ & 11 & $-0,25$ \\
\hline Podkarpackie & $-0,39$ & 12 & $-0,39$ & 12 & $-0,24$ & 12 & $-0,40$ & 12 & $-0,36$ \\
\hline Świętokrzyskie & $-0,51$ & 14 & $-0,41$ & 13 & $-0,52$ & 15 & $-0,45$ & 14 & $-0,39$ \\
\hline $\begin{array}{l}\text { Warmińsko- } \\
\text { mazurskie }\end{array}$ & $-0,43$ & 13 & $-0,44$ & 14 & $-0,48$ & 14 & $-0,44$ & 13 & $-0,52$ \\
\hline Lubelskie & $-0,57$ & 15 & $-0,60$ & 15 & $-0,46$ & 13 & $-0,52$ & 15 & $-0,55$ \\
\hline Podlaskie & $-0,58$ & 16 & $-0,68$ & 16 & $-0,58$ & 16 & $-0,63$ & 16 & $-0,61$ \\
\hline
\end{tabular}

Źródło: opracowanie IBnGR (2015).

IBnGR (2014) sklasyfikował także województwa z uwzględnieniem najpopularniejszych czynników atrakcyjności inwestycyjnej. Wyniki pokazują, jak poszczególne województwa plasują się w rankingu w odniesieniu do czynników atrakcyjności w 2014 roku (tabela 3).

Tabela 3. Ranking województw w 2014 roku

\begin{tabular}{|c|c|c|c|c|c|c|c|c|c|c|c|}
\hline $\begin{array}{l}\sum_{N}^{0} \\
\frac{1}{0} \\
\frac{0}{0} \\
\frac{0}{0} \\
3\end{array}$ & 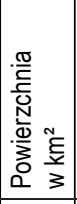 & 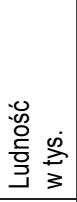 & 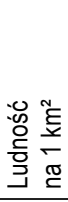 & 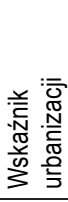 & 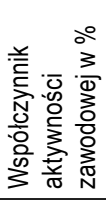 & 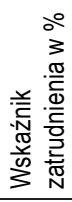 & 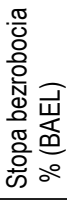 & 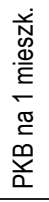 & 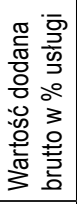 & 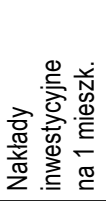 & 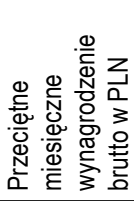 \\
\hline Dolnośląskie & 7 & 5 & 4 & 2 & 10 & 8 & 9 & 2 & 16 & 2 & 3 \\
\hline $\begin{array}{l}\text { Kujawsko- } \\
\text { pomorskie }\end{array}$ & 10 & 10 & 9 & 9 & 8 & 11 & 14 & 10 & 10 & 14 & 12 \\
\hline Lubelskie & 3 & 8 & 12 & 14 & 4 & 7 & 13 & 15 & 3 & 13 & 9 \\
\hline Lubuskie & 13 & 15 & 14 & 7 & 12 & 10 & 4 & 9 & 14 & 10 & 14 \\
\hline Łódzkie & 9 & 6 & 5 & 6 & 2 & 3 & 8 & 6 & 11 & 3 & 8 \\
\hline Małopolskie & 12 & 4 & 2 & 13 & 5 & 5 & 9 & 7 & 4 & 9 & 5 \\
\hline
\end{tabular}




\begin{tabular}{|c|c|c|c|c|c|c|c|c|c|c|c|}
\hline $\begin{array}{l}\frac{10}{3} \\
\frac{1}{8} \\
\frac{0}{0} \\
\frac{0}{3} \\
3\end{array}$ & 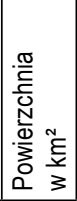 & 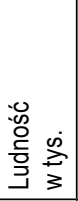 & 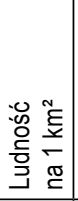 & 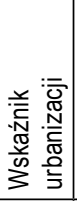 & 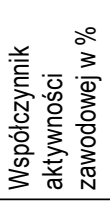 & 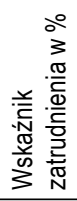 & 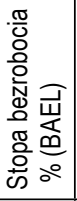 & 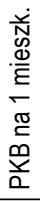 & 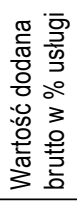 & 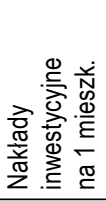 & 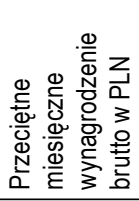 \\
\hline Mazowieckie & 1 & 1 & 3 & 5 & 1 & 1 & 1 & 1 & 1 & 1 & 1 \\
\hline Opolskie & 16 & 16 & 11 & 12 & 13 & 9 & 3 & 11 & 13 & 11 & 7 \\
\hline Podkarpackie & 11 & 9 & 7 & 16 & 11 & 15 & 16 & 16 & 7 & 7 & 15 \\
\hline Podlaskie & 6 & 14 & 16 & 8 & 5 & 5 & 9 & 14 & 5 & 12 & 11 \\
\hline Pomorskie & 8 & 7 & 6 & 4 & 7 & 4 & 6 & 5 & 6 & 5 & 4 \\
\hline Śląskie & 14 & 2 & 1 & 1 & 14 & 12 & 6 & 4 & 15 & 6 & 2 \\
\hline Świętokrzyskie & 15 & 13 & 10 & 15 & 8 & 13 & 15 & 12 & 9 & 16 & 13 \\
\hline $\begin{array}{l}\text { Warmińsko- } \\
\text { mazurskie }\end{array}$ & 4 & 12 & 15 & 10 & 16 & 16 & 12 & 13 & 8 & 15 & 16 \\
\hline Wielkopolskie & 2 & 3 & 8 & 11 & 3 & 2 & 2 & 3 & 12 & 8 & 10 \\
\hline Zachodniopomorskie & 5 & 11 & 13 & 3 & 15 & 14 & 5 & 8 & 2 & 4 & 6 \\
\hline
\end{tabular}

Źródło: opracowanie własne na podstawie danych z gus.gov.pl (18.11.2015).

W kategorii definicji ekonomicznych atrakcyjność inwestycyjna pozostaje w bliskim związku z posiadanym przez region potencjałem rozwojowym. Wielowymiarowy charakter tych dwóch kategorii ekonomicznych sprawia, że częściowo opisują one ten sam problem, czyli możliwości rozwoju regionów. W przypadku atrakcyjności inwestycyjnej jest to prawdopodobieństwo lub skala realizowanych inwestycji, podczas gdy dla potencjału rozwojowego jest to zasób i stopień wykorzystania czynników warunkujących rozwój na poziomie regionalnym. Badania nad atrakcyjnością inwestycyjną doprowadziły do istotnego zbliżenia tych dwóch kategorii ekonomicznych, co częściowo jest uwarunkowane dostępnością danych w różnych przekrojach terytorialnych.

\section{Determinanty wpływające na atrakcyjność inwestycyjną}

W literaturze przedmiotu występuje wiele opracowań poświęconych tematowi determinant atrakcyjności inwestycyjnej. Opracowania dzielone są według różnorodnych kryteriów, np. twarde - miękkie, powszechne - unikatowe, jakościowe - ilościowe. Występują także różne podejścia do kwalifikacji poszczególnych czynników wpływających na atrakcyjność, przyznawania im rang, wartościowaniu ich znaczenia. Uniwersalne opracowanie zestawu determinant atrakcyjności inwestycyjnej jest niewątpliwe trudnym zadaniem. Sprawę komplikuje to, że każdy z inwestorów inaczej odbiera atrakcyjność danego regionu, patrząc przez pryzmat swojej działalności. Wymienione czynniki dla każdego inwestora będą miały odrębne znaczenie. W zależności od jego produkcji, działalności i potrzeb, wskazane determinanty będą klasyfikowane przez inwestorów za 
pomocą innych rang ważności. Dodatkowo kwestię tzw. uniwersalnego podejścia do atrakcyjności implikują indywidualne uwarunkowania danego regionu. Często dostępne tylko na wybranych obszarach (np. dostęp do morza, liczne zabytki kultury, położenie przygraniczne, poszukiwane zasoby naturalne, rozwinięte centra naukowe lub działające specjalne strefy ekonomiczne) powodują, że dany region na starcie jest na wyższym poziomie atrakcyjności inwestycyjnej w porównaniu z sąsiadującą jednostką terytorialną. Z punktu widzenia mieszkańca region jest atrakcyjny wówczas, gdy jest dostępny dla niego pod względem kultury, edukacji, zdrowia czy bezpieczeństwa publicznego, a z punktu widzenia władzy region jest atrakcyjny wtedy, gdy strefa gospodarki jest rozwinięta i konkurencyjna. W tabeli 4 przedstawiono zestawienie determinant atrakcyjności inwestycyjnej w obszarze infrastruktury społecznej i gospodarczej.

Tabela 4. Wybrane determinanty atrakcyjności inwestycyjnej

\begin{tabular}{|c|c|}
\hline Infrastruktura & Determinanty atrakcyjności inwestycyjnej \\
\hline 1 & 2 \\
\hline Gospodarcza & $\begin{array}{l}\text { - dostępność transportowa regionu } \\
\text { - położenie geograficzne regionu } \\
\text { - infrastruktura ekologiczna } \\
\text { - stan infrastruktury technicznej } \\
\text { - infrastruktura wodno-kanalizacyjna } \\
\text { - kondycja ekonomiczna istniejących podmiotów } \\
\text { - gospodarka odpadami } \\
\text { - rozwój ośrodków metropolitalnych } \\
\text { - funkcjonowania specjalnych stref ekonomicznych } \\
\text { - wykorzystanie funduszy strukturalnych przeznaczonych na rozwój regionu } \\
\text { - instytucje otoczenia biznesu } \\
\text { - stan ochrony środowiska } \\
\text { - gospodarka mieszkaniowa } \\
\text { - infrastruktura telekomunikacyjna } \\
\text { - instytucje finansowe } \\
\text { - struktura zagranicznych inwestycji } \\
\text { - oferowane ulgi inwestycyjne } \\
\text { - rozwój sfery małej i średniej przedsiębiorczości }\end{array}$ \\
\hline Społeczna & $\begin{array}{l}\text { - funkcjonowanie organizacji pozarządowych } \\
\text { - infrastruktura kulturalna i kulturowa } \\
\text { - infrastruktura oświatowa } \\
\text { - otoczenie naukowe } \\
\text { - infrastruktura rekreacyjno-wypoczynkowa } \\
\text { - istniejacce zasoby pracy } \\
\text { - dostępność do oddziałów pomocy medycznej } \\
\text { - dostępność środowiska naturalnego } \\
\text { - bezpieczeństwo powszechne }\end{array}$ \\
\hline
\end{tabular}

Źródło: opracowanie własne na podstawie: (Piech, 2009); (Pietrzyk, 2000); (Stimson, Stough, Roberts, 2006).

Większość z przedstawionych determinant ma charakter tradycyjny i pojawia się w wielu opracowaniach dotyczących atrakcyjności inwestycyjnej czy konkurencyjności regionów w różnych hierarchiach wartości. Poziom atrakcyjności inwestycyjnej gminy 
ma bezpośrednie przełożenie na jej możliwości konkurencyjne w procesie pozyskiwania inwestorów. Identyfikacja determinant ekonomicznych i barier rozwoju lokalnego jest istotna z punktu widzenia podejmowania właściwych decyzji w procesie stymulowania rozwoju społeczno-gospodarczego kraju/regionu. W literaturze przedmiotu wymienia się wiele uniwersalnych czynników determinujących atrakcyjność inwestycyjną regionów z podziałem na miękkie i twarde. Nowicki (2010) do czynników miękkich zalicza zmienne infrastruktury społecznej, chłonność rynku, zasoby pracy, natomiast jako czynniki twarde wymienia infrastrukturę gospodarczą, dostępność transportową, poziom rozwoju gospodarczego oraz aktywność województw wobec inwestorów. Zarówno determinanty twarde, jak i miękkie często występują w zależności od siebie, co potencjalnie korzystnie wpływa na atrakcyjność inwestycyjną. Podział ten przedstawia poniższy rysunek 2 .
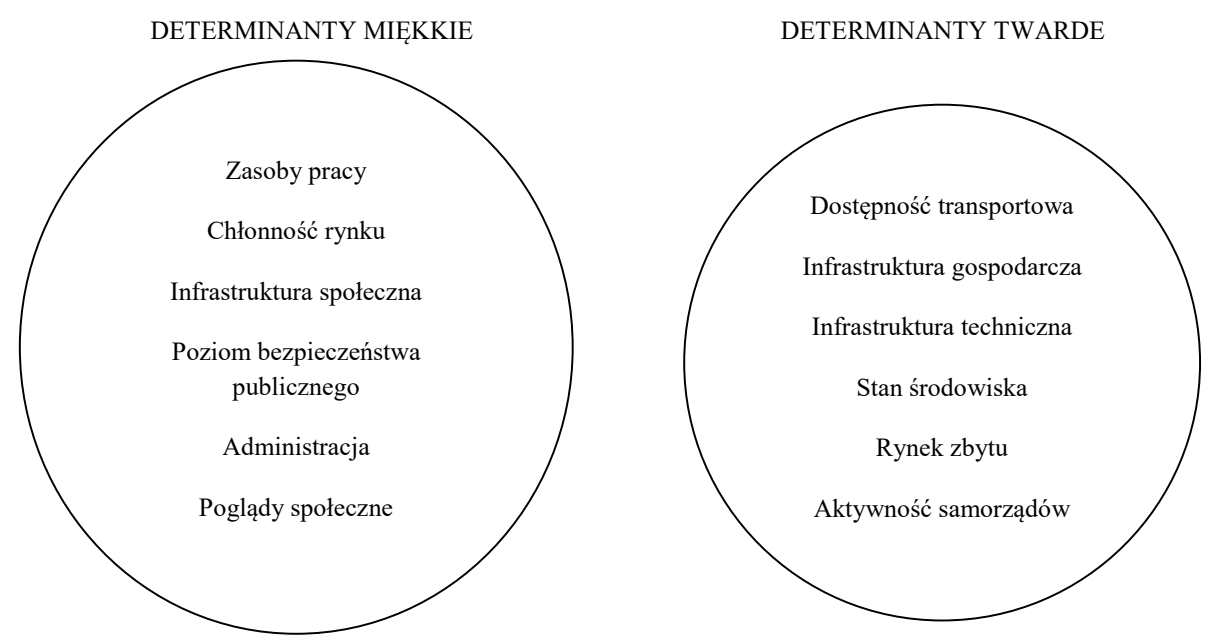

Rysunek 2. Podział determinant atrakcyjności inwestycyjnej

Źródło: opracowanie własne na podstawie: (Nowicki, 2010); (Godlewska-Majkowska, 2010).

\section{Ograniczenia budżetowe jednostek samorządu terytorialnego}

Polityka finansowa Unii Europejskiej w nowej perspektywie finansowej 2014-2020 w głównej mierze oparta jest na realizacji budżetu, który w swoim założeniu planuje przychody i wydatki oraz służy realizacji przyjętej polityki społecznej i gospodarczej państw członkowskich (Porębska, 2014). Budżet UE tworzą zasoby finansowe wszystkich jej członków, umożliwiając tym samym realizację głównego celu działalności Unii Europejskiej polegającego na zmniejszeniu różnic ekonomicznych i społecznych 
w rozwoju występujących między regionami a krajami Europy. Przystąpienie Polski do UE stworzyło nowe możliwości dla jednostek samorządu terytorialnego we wszystkich obszarach funkcjonowania. Jedną z najważniejszych korzyści, wynikających z członkostwa we Wspólnocie, jest m.in. możliwość korzystania z funduszy pomocowych, które W znacznej mierze sprzyjają rozwojowi, jak również promocji regionów. W. Misterek (2008) twierdzi, że odpowiednio wcześniejsze zaplanowanie inwestycji w jednostkach samorządowych umożliwia wykorzystanie środków z Unii Europejskiej, które w istotny sposób wspomagają własne, ograniczone możliwości finansowania zadań i niejednokrotnie okazują się niezbędne do ich rozwoju.

Porębska (2014) słusznie zauważa, że na sytuację finansową jednostek samorządu terytorialnego ma istotny wpływ wiele różnych uwarunkowań. Według badań przeprowadzonych na zlecenie Ministerstwa Rozwoju Regionalnego (MRR, 2013), do głównych zewnętrznych uwarunkowań ograniczeń budżetowych JST należą:

- dynamika wzrostu PKB, czego następstwem jest wzrost dochodów budżetowych,

- poziom inflacji (wpływający na obniżenie realnych dochodów samorządów),

- procedury ograniczenia deficytu Polski,

- ograniczenie transakcji na rynku nieruchomości - negatywnie wpływa na możliwość pozyskiwania dochodów ze sprzedaży majątku komunalnego oraz wpływów podatkowych z nimi związanych (podatek od czynności cywilnoprawnych),

- pozyskiwanie dotacji unijnych wykorzystywanych na finansowanie nowych inwestycji (napływ środków z UE pozwolił utrzymać spadkowy trend deficytu budżetowego jednostek samorządu terytorialnego a nawet na czasową poprawę ich płynności finansowej),

- wzrastające koszty bieżące funkcjonowania jednostek samorządu terytorialnego, w następstwie czego ograniczony zostaje ich potencjał rozwojowy (np. wydatki gmin wynikające z zapisów ustawy Karta Nauczyciela),

- zmiana rozwiązań regulacyjnych rozszerzająca definicję kredytów i pożyczek zaliczanych do długu, w następstwie czego wykazano wzrost zadłużenia JST.

Od 2009 roku w Polsce zauważalny jest spadek dochodów zarówno budżetu państwa, jak i budżetów JST. Przeciwdziałając kryzysowi finansowemu, od 2010 roku podjęto określone działania zmierzające do poprawy stanu finansów publicznych. Polegały one przede wszystkim na dążeniu do obniżenia wydatków publicznych względem PKB. Pomimo licznych regulacji, jak np. podniesienie stawki VAT, podwyżka składki rentowej, zamrożenie progów podatkowych i kwoty wolnej od podatku od osób fizycznych, dochody sektora publicznego wzrosły w niewielkim stopniu. W 2013 roku deficyt sektora instytucji rządowych i samorządowych stanowił - 4,3\% PKB (rysunek 3). 


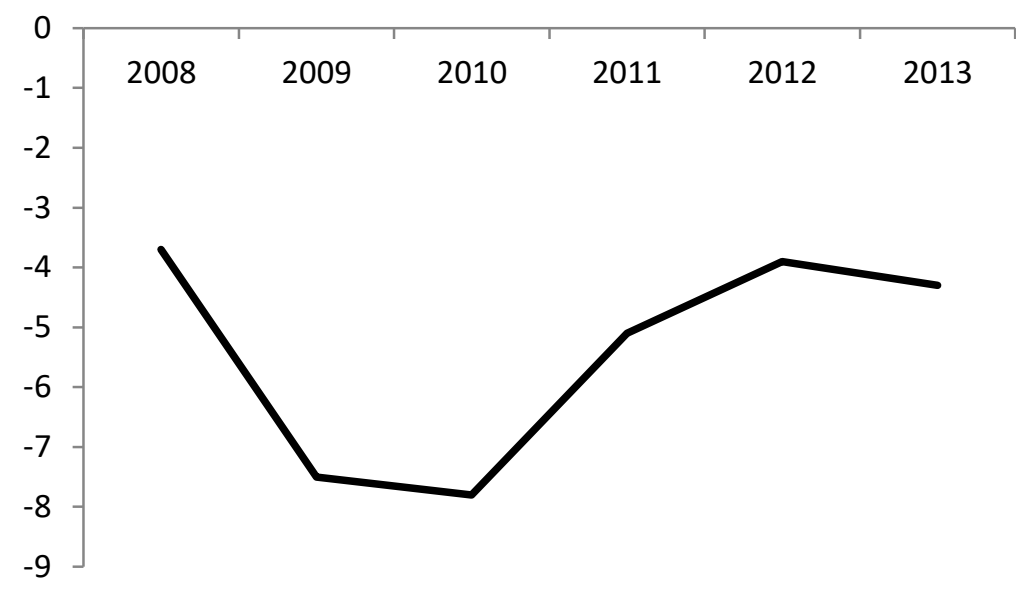

Rysunek 3. Deficyt sektora rządowego i samorzadowego w latach 2008-2013

Źródło: opracowanie własne na podstawie prognozy General government deficyt (-) and surpuls (+) - annual data, www.wpp. eurostat.ec.europa.eu. Za: (Porębska, 2014).

Konsekwencją wysokiego deficytu budżetowego było w 2011 roku nałożenie przez Unię Europejską tymczasowej wydatkowej reguły dyscyplinującej, która ograniczała tempo wzrostu planowanych wydatków. Reguła ta ma na celu stabilizację finansów publicznych poprzez określenie dopuszczalnego wzrostu wydatków sektora publicznego. Następstwem tego działania było wprowadzenie ustawy o finansach publicznych w 2014 r. indywidualnego wskaźnika wyznaczającego górną granicę zadłużenia (IWZ). W konsekwencji ograniczał on możliwości zaciągania zobowiązań przez JST. W sytuacji zastosowania IWZ wiele samorządów miało ograniczone możliwości pozyskania środków z zewnętrznych źródeł finansowania. B. Porębska (2014) twierdzi, że dla sfinansowania wytyczonych celów rozwojowych niejednokrotnie zachodzi taka konieczność. W latach 2011-2013 dług samorządów wyniósł średnio ponad 65 mld PLN i stanowił 38\% ich dochodów. W 2013 roku 3,2\% JST osiągnęło 60\% progu łącznej kwoty zadłużenia w stosunku do dochodów budżetowych. Jak wskazują szacunki Ministerstwa Infrastruktury i Rozwoju, niektóre miasta w nowej perspektywie finansowej mogą mieć z powodu unijnych inwestycji problemy z utrzymaniem równowagi budżetowej. W latach 2014-2020 wkład własny ze strony JST będzie wynosił ok. 36\% wartości inwestycji. Porębska (2014) zwraca uwagę, że analizując kondycję finansową JST, w najbliższym okresie programowym wiele jednostek samorządowych będzie miało ograniczoną możliwość zaciągania zobowiązań, tak aby nie przekroczyć ustawowych limitów zadłużenia. Autorka zwraca także uwagę na problem największej bariery JST, związanej z koniecznością zapewnienia wkładu własnego przekraczającego możliwości finansowe poszczególnych samorządów. Pomimo że wymieniana jest przez 
wszystkie raporty i analizy rzadziej niż skomplikowane procedury aplikowania o środki, staje się istotna dla JST, ponieważ negatywnie wpływa na absorpcję funduszy przez samorząd w latach 2014-2017. Oprócz obowiązującego wskaźnika IWZ, na sytuację finansową JST wpływają inne uwarunkowania zewnętrzne. Jak wynika z badań przeprowadzonych na zlecenie Ministerstwa Rozwoju Regionalnego, do głównych czynników zewnętrznych należą:

- dynamika wzrostu PKB, której następstwem jest wzrost dochodów budżetowych,

- poziom inflacji - wpływający na obniżenie realnych dochodów samorządów,

- procedury ograniczenia deficytu Polski,

- ograniczenie transakcji na rynku nieruchomości negatywnie oddziałujące na możliwość pozyskiwania dochodów ze sprzedaży majątku komunalnego oraz wpływów podatkowych z nimi związanych (podatek od czynności cywilnoprawnych),

- pozyskiwanie dotacji unijnych, wykorzystywanych na finansowanie nowych inwestycji.

Bariery JST o charakterze finansowo-prawnym w nowym okresie programowania funduszy strukturalnych są istotne, ponieważ wpływają negatywnie na możliwości absorpcji środków zewnętrznych przez samorządy. O ile w procesie pozyskiwania funduszy nadmierna liczba wymaganych dokumentów nie stanowi poważnej przeszkody dla samorządów, to wymagany procent wkładu własnego, jaki muszą wnieść wnioskodawcy, dla wielu z nich staje się znaczącym ograniczeniem. Stwarza to zagrożenie niewykorzystania puli środków unijnych, skierowanych do samorządów w nowej perspektywie finansowej 2014-2020, co w konsekwencji doprowadzić może do obniżenia atrakcyjności inwestycyjnej regionów.

\section{Podsumowanie}

Rozmiar funduszy unijnych przyznanych w budżecie Unii Europejskiej samorządom w perspektywie finansowej na lata 2014-2020 stwarza nowe możliwości dla rozwoju społeczno-gospodarczego regionów. Biorąc pod uwagę zmienione przepisy prawne w zakresie finansów publicznych, odnoszących się przede wszystkim do JST, pojawia się ryzyko niewykorzystania całej puli środków z funduszy Unii Europejskiej przewidzianych dla Polski. Na taką sytuację wpływa bariera finansowa, która ma na celu utrzymanie odpowiedniego poziomu deficytu budżetowego państwa, a co za tym idzie, deficytu jednostek samorządu. Jednostki samorządu terytorialnego były w ostatnich latach szczególnie ważne z punktu widzenia rozwoju gospodarczego Polski. Samorządy, inicjując wiele inwestycji z wykorzystaniem środków unijnych, wpływają na rozwój gospodarczy kraju. Możliwość utrzymania tej tendencji w nowej perspektywie finansowej 
UE w latach 2014-2020 jest uzależniona od wielu uwarunkowań. Rzeczywistym zagrożeniem dla sprawnej absorpcji środków pomocowych jako instrumentów finansowania inwestycji może okazać się „niewydolność” finansowa samorządu terytorialnego, związana ze skutkami obserwowanego kryzysu gospodarczego/finansowego oraz koniecznością przestrzegania nowych limitów zadłużenia. Preferowany przez Unię Europejską zrównoważony rozwój w Polsce może nie udać się w takim stopniu, jak w minionym okresie programowania. Dodatkowo w polityce strukturalnej UE zdecydowanie większy nacisk jest położony na kwestie efektywności ekonomicznej realizowanych projektów inwestycyjnych. Każda jednostka samorządowa dąży do uzyskania przewagi konkurencyjnej pod względem atrakcyjności inwestycyjnej, ponieważ pozyskiwanie przedsiębiorców i powstawanie nowych inwestycji bezpośrednio przekłada się na zwiększanie dochodów budżetowych gminy, a zwłaszcza dochodów własnych, z których później można finansować zadania służące rozwojowi lokalnej społeczności. Zakończony okres programowania 2007-2013 skłania do stwierdzenia, że inwestycje dofinansowane z środków Unii Europejskiej przyczyniły się do znacznego rozwoju samorządów i podniesienia rangi gospodarczej regionów. Mając na względzie zarówno dokumenty strategiczne regulujące politykę Unii Europejskiej, jak i rozwój samorządów w nowej perspektywie finansowej na lata 2014-2020 oraz zdobyte doświadczenie w wdrażaniu funduszy strukturalnych, główne kierunki działań samorządowych powinny być skierowane w stronę niszy pojawiającej się w obszarach: transportu kolejowego, bezpieczeństwa energetycznego, gospodarki niskoemisyjnej i infrastruktury internetu szerokopasmowego. Bardzo ważna jest nadal realizacja działań związanych ze wzrostem zatrudnienia, walką z ubóstwem oraz zwiększeniem nakładów finansowych na badania naukowe i rozwój technologii.

\section{Literatura}

Adamowicz, M. (2003). Kształtowanie rozwoju regionalnego. Warszawa: SGGW.

Atkinson, R., Madsen, B., Russo, B., Servillo, L., Smith, I., Van der Borg, J. (2010). ATTREG: The Attractiveness of European Region and Cities for Residents and Visitors, ESPON. Tarragona: University Rovira i Virgili.

Bojar, E. (2001). Bezpośrednie inwestycje zagraniczne w obszarach słabo rozwiniętych. Lublin: PWN.

Bossak, J., Bieńkowski, W. (2013). Międzynarodowa zdolność konkurencyjna kraju i przedsiębiorstw. Wyzwania dla Polski na progu XXI wieku. Warszawa: SGH.

Chojnacka K., (2007). Atrakcyjność inwestycyjna województw w świetle badań IBnGR. W: J. Kot (red.), Konkurencyjność i innowacyjność regionów w warunkach globalizacji i metropolizacji przestrzeni (s. 144). Kielce: Akademia Świętokrzyska.

Dunning, J.H. (1993). Multinational Enterprises and the Global Economy. Journal of Finance and Economics, 2 (3), 70-74. DOI: 10.12691/jfe-2-3-3. 
Gawlikowska-Hueckel, K., Umiński, S., (2000). Ocena konkurencyjności województw. Gdańsk: IBnGR.

Godlewska-Majkowska, H. (2008). Istota atrakcyjności inwestycyjnej regionów. W: H. Godlewska-Majkowska (red.), Atrakcyjność inwestycyjna polskich regionów. W poszukiwaniu nowych miar (s. 20). Warszawa: SGH.

Godlewska-Majkowska, H. (2011). Atrakacyjność inwestycyjna regionów Polski na tle Unii Europejskiej. Warszawa: SGH.

Godlewska-Majkowska, H., (2012). Metodyka parametryzacji atrakcyjności inwestycyjnej regionów. Warszawa: SGH.

Guzik, B. (2010), Inwestycje w sektorze prywatnym. Wiadomości Statystyczne, 1, 66.

Kalinowski, T. (2005). Atrakcyjność inwestycyjna województw i podregionów Polski. W: T. Kalinowski (red.), Atrakcyjność inwestycyjna województw i podregionów Polski (s. 11-90). Gdańsk: IBnGR.

Lizińska, W., Kisiel, R. (2005). Bezpośrednie inwestycje zagraniczne na obszarach wiejskich województwa warmińsko-mazurskiego. W: W. Karaszewski (red.), Bezpośrednie inwestycje zagraniczne w podnoszeniu konkurencyjności polskiej gospodarki (s. 195). Toruń: Wyd. UMK.

Lizińska, W., Marks-Bielska, R., Kisiel, R. 2011. Atrakcyjność inwestycyjna gmin i znaczenie w jej kształtowaniu preferencji Specjalnej Strefy Ekonomicznej. Roczniki Nauk Rolniczych, Seria G, 98 (3), 198.

Misterek, W. (2008). Zewnętrzne źródła finansowania działalności inwestycyjnej jednostek samorzadu terytorialnego. Warszawa: Difin.

Nazarczuk, M. J., (2001). Potencjat rozwojowy a aktywność inwestycyjna województw i regionów Polski. Olsztyn: Wydawnictwo Uniwersytetu Warmińsko-Mazurskiego.

Nowicki, M. (red.) (2013). Atrakcyjność inwestycyjna województw i podregionów Polski 2013. Gdańsk: IBnGP.

Nowicki, M. (red.) (2014). Atrakcyjność inwestycyjna województw i podregionów Polski 2013. Gdańsk: IBnGP.

Parysek, J. (1995). Rola samorządu terytorialnego w rozwoju lokalnym. W: J. Parysek (red.), Rozwój lokalny: Zagospodarowanie przestrzenne i nisze atrakcyjności gospodarczej (s. 90 120), Warszawa: PAN.

Poniatowicz, M. (2014). Uwarunkowania aktywności inwestycyjnej samorządu terytorialnego w Polsce w nowej perspektywie finansowej 2014-2020. Zeszyty Naukowe Uniwersytetu Szczecińskiego, 841, 175.

Porębska, B. (2014). Szanse i zagrożenia dla jednostek samorządu terytorialnego w nowej perspektywie finansowej 2014-2020. Zeszyty Naukowe Uniwersytetu Szczecińskiego, 841, 192.

Sierak, J., Bitner, M. (2013). Oszacowanie środków niezbędnych do zapewnienia krajowego wkładu publicznego do projektów realizowanych $w$ ramach średniookresowych ram finansowych 2014-2020. Warszawa: MRR.

Stawicka, M., Kwieciński, L., Wróblewski, M. (2010). Analiza atrakcyjności inwestycyjnej regionu $w$ świetle współczesnych trendów. Wrocław: Urząd Marszałkowski Województwa Dolnośląskiego.

Stimson, R.J., Stough, R.R., Roberts, B.H. (2006). Regional economic develompment. Analysis and Planning Strategy. Berlin: Springer.

Żelazko, B., (2008). Marketing jako czynnik podnoszący atrakcyjność inwestycyjną regionów w teorii i praktyce badawczej. W: W. Szczęsny (red.), Atrakcyjność inwestycyjna polskich regionów (s. 109). Warszawa: PTE. 
10 lat PL-UE. Polskie 10 lat w Unii. Raport (2014). Warszawa: Ministerstwo Spraw Zagranicznych.

Strategia zarządzania długiem sektora finansów publicznych w latach 2014-2017 (2013), Warszawa: Ministerstwo Finansów.

Programowanie perspektywy finansowej 2014-2020 - uwarunkowania strategiczne (2012). Warszawa: Ministerstwo Infrastruktury i Rozwoju.

\begin{abstract}
Abstrakt
Aktywność inwestycyjna stanowi nieodłączny strategiczny element funkcjonowania samorządu terytorialnego. Polskie jednostki samorządu terytorialnego są kluczowym inwestorem w sektorze publicznym, finansujac blisko $3 / 4$ inwestycji tego sektora. Środki pomocowe Unii Europejskiej (Poniatowicz, 2014), stanowią istotny impuls wzrostu aktywności inwestycyjnej jednostek samorządu terytorialnego. Wszystko wskazuje na to, że tendencja ta zostanie utrzymana, a nawet wzmocniona w nowej perspektywie finansowej UE, tj. w latach 2014-2020. Celem opracowania jest identyfikacja najważniejszych czynników ekonomicznych i społecznych warunkujących wzrost atrakcyjności inwestycyjnej jednostki samorządu terytorialnego w aspekcie ograniczeń budżetowych. Jako kluczowe determinanty w tym zakresie określono: 1) stan gospodarki; 2) wyniki operacyjne jednostek samorządu terytorialnego; 3) wykorzystanie przez samorząd terytorialny instrumentów dotacyjnych UE; 4) możliwości zapewnienia przez samorząd terytorialny tzw. wkładu własnego, wymaganego przy absorpcji środków unijnych. Do uzyskania danych zastosowano przegląd literatury, dostępnych danych statystycznych i opracowań raportowych, co pozwoliło na określenie ekonomicznych uwarunkowań wpływających na atrakcyjność inwestycyjną regionów w świetle problematyki ograniczeń budżetowych.
\end{abstract}




\section{Economic determinants of investment attractiveness in the background of budget constraints}

The size of EU funds allocated to the local government budget in the 2014-2020 financial perspective creates new opportunities for socio-economic development of the regions. However, taking into account the revised legal regulations in the area of public finances, which concern primarily local government units, there is a risk of not using the entire envelope from the European Union funds provided for Poland. Such a situation is influenced by the financial barrier, which aims at maintaining an adequate level of the state budget deficit and, consequently, the deficit of self-government units. Local government units have been particularly important from the point of view of Poland's economic development in recent years. Local governments, when initiating a series of investments using EU funds, influence the economic development of the country. The possibility of maintaining this trend in the new EU financial perspectives 20142020 is conditional on a number of determinants. The real threat to the smooth absorption of aid as a financing instrument for investment may be the financial "failure" of local government, linked to the effects of the observed economic / financial crisis, and the need to respect new debt limits. The European Union's preference for sustainable development in Poland may not be such a speculative result as it did in the past programming period. In addition, in the EU structural policy, there is much greater emphasis on the economic efficiency of investment projects. Each local government unit is striving for a competitive advantage in terms of investment attractiveness, since the acquisition of entrepreneurs and the creation of new investments directly translate into increasing the budgetary income of the municipality, and in particular its own revenue, which can later be financed for the development of the local community. The completed programming period 2007-2013 leads to the conclusion that investments co-financed by the European Union contributed to the significant development of self-governments and the rise of the economic status of the regions. Bearing in mind the strategic documents regulating the policy of the European Union as well as the development of self-governments in the new financial perspective for 2014-2020 and the experience gained in implementing the Structural Funds, the main directions of local government actions should be directed towards the niche emerging in the areas of rail transport, energy security, low carbon economy and broadband internet infrastructure. It is extremely important to carry out activities related to employment growth, the fight against poverty, increased funding for research and technological development. 